\title{
Long term respiratory outcomes following solid organ transplantation in children: a retrospective cohort study.
}

\author{
Marie Wright ${ }^{1}$, Mark Chilvers ${ }^{1}$, and Tom Blydt-Hansen ${ }^{1}$ \\ ${ }^{1}$ BC Children's Hospital
}

September 25, 2021

\begin{abstract}
Background Solid organ transplantation (SOT) has become commonly used in children and is associated with excellent survival rates into adulthood. Data regarding long-term respiratory outcomes following pediatric transplantation are lacking. We aimed to describe the prevalence and nature of respiratory pathology following pediatric heart, kidney, and liver transplant, and identify potential risk factors for respiratory complications. Methods Retrospective review involving all children under active follow-up at the provincial transplant service in British Columbia, Canada, following SOT. Results Of 118 children, $33 \%$ experienced respiratory complications, increasing to $54 \%$ in heart transplant recipients. Chronic or recurrent cough with persistent chest $\mathrm{x}$-ray changes was the most common clinical picture, and most infections were with non-opportunistic organisms typically found in otherwise healthy children. A history of respiratory illness prior to transplant was significantly associated with risk of posttransplant respiratory complications. $8 \%$ were diagnosed with bronchiectasis, which was more common in recipients of heart and kidney transplant. Bronchiectasis was associated with recurrent hospital admissions with lower respiratory tract infections, treatment of acute rejection episodes, and treatment with sirolimus. Interpretation Respiratory morbidity is common after pediatric SOT, and bronchiectasis rates were disproportionately high in this patient group. We hypothesise that this relates to recurrent infections resulting from iatrogenic immunosuppression. Direct pulmonary toxicity from immunosuppression drugs may also be contributory. A high index of suspicion for respiratory complications is needed following childhood SOT, particularly in those with a history of respiratory disease prior to transplant, experiencing recurrent or severe respiratory tract infections, or exposed to intensified immunosuppression.
\end{abstract}

\section{Hosted file}

SOT for ppulm main document for upload.docx available at https://authorea.com/users/436894/ articles/538909-long-term-respiratory-outcomes-following-solid-organ-transplantation-inchildren-a-retrospective-cohort-study

\section{Hosted file}

Table 1.docx available at https://authorea.com/users/436894/articles/538909-long-termrespiratory-outcomes-following-solid-organ-transplantation-in-children-a-retrospectivecohort-study

\section{Hosted file}

Table 2.docx available at https://authorea.com/users/436894/articles/538909-long-termrespiratory-outcomes-following-solid-organ-transplantation-in-children-a-retrospectivecohort-study

\section{Hosted file}


Table 3.docx available at https://authorea.com/users/436894/articles/538909-long-termrespiratory-outcomes-following-solid-organ-transplantation-in-children-a-retrospectivecohort-study

\section{Hosted file}

Figure 1.docx available at https://authorea.com/users/436894/articles/538909-long-termrespiratory-outcomes-following-solid-organ-transplantation-in-children-a-retrospectivecohort-study

\section{Hosted file}

Figure 2.docx available at https://authorea.com/users/436894/articles/538909-long-termrespiratory-outcomes-following-solid-organ-transplantation-in-children-a-retrospectivecohort-study 